\title{
Determining the Priority Strategy in the Implementation of E-Government Through Swot Analysis Model
}

\author{
${ }^{1}$ Otong Karyono, ${ }^{2}$ Kania Agustina \\ ${ }^{(1)(2)}$ Postgraduate Program - Majalengka University, Indonesia \\ ${ }^{1}$ karyono.otong@gmail.com ${ }^{2}$ kaniaagustina999@yahoo.com
}

\begin{abstract}
Abtsract : The implementation of technology and information in the government environment or Electronic Government (E-Government) is a very important factor to be carried out by the government in order to implement more responsive, transparent, accountable services to realize a more quality service system in responding to the challenges of technological development today. Thus, the government, society, and business parties can access information and transact quickly, precisely and cheaply. Therefore, the strategy formulation is indispensable in responding to challenges and weaknesses to maximize strengths and opportunities. The strategy formulation that is considered relevant for conducting this present research is the SWOT analysis. This research uses a descriptive qualitative research model by identifying strengths, weaknesses, opportunities, and threats through research questionnaires and interviews conducted on 30 employees involved in the process of public service activities. Technique for analyzing internal and external business environments uses SWOT. The results show that by considering the strengths and weaknesses as well as external factors to take into account the opportunities and threats, it can be seen that the appropriate strategies to realize the implementation of E-Government to achieve quality service is the aggressive strategy, which refers to the strategy of development regarding very good situations because there are strengths to be utilized to seize profitable opportunities.
\end{abstract}

Keywords : Strategy; E-Government; SWOT Analysis.

\section{Introduction}

The existence of the government is closely related to the function of public service. Progress in the field of technology and information is one of the challenges for the government in providing more effective, efficient and accountable services. The technology advance characterized by technology digitalization requires the government to better deliver quality of service by utilizing all of the resources the government has and improving performance. E-Government provides many benefits to the government in creating more modern and innovative services (Kahraman, Demirel, and Demirel 2007); (Al Salmi and Bt Hasnan 2015). Moreover, the current government challenges are characterized by the emergence of AFTA (Asean Free Trade Area) and AEC (Asean Economic Community) which have been enforced since 2015. It can automatically affect the process of product licensing in the country to obtain the legal power in order to be able to compete with foreign products. One government institution has been established to manage the licensing sector. The central government simplifies the institution to improve ease and efficiency of licensing process into one door, namely Badan Pusat Pelayanan Terpadu dan Penanaman Modal (BPPT-PM) or the Integrated Service and Investment Center Institution.

Majalengka Regency is currently working in facing free trade flows due to the presence of West Java International Airport. Hence there are a lot of new business activities have sprung up in Majalengka. With the large number of new businesses, this certainly affects the intensity of BPPT-PM in providing quality service. Therefore, a strategy is needed to answer challenges and weaknesses by utilizing all factors of strengths and opportunities by BPPT- 
PM. (Hussain, Saghir, and Khalil 2016); (Tresna 2017) in their research confirmed that observations of external and internal environmental factors became the determinant achieving the stated goals. This research, hence, tries to provide an alternative solution in designing a strategy by taking into account some external and internal factors in order to improve EGovernment based and quality public services. SWOT analysis is an analysis that is very appropriate to conduct a review of external factors such as opportunities and challenges, as well as internal factors in the form of strengths and weaknesses as the basis in the formulation of the strategy to be implemented. SWOT analysis is the basis for developing priority strategy as well as evaluating strategies that have been carried out in realizing effective and efficient E-Government implementation to achieve quality public services (Abdulla and Sherwani 2017);(Ha 2012). Based on the above explanation, the researcher intends to conduct a comprehensive research on the Implementation of E-Government Strategy through SWOT Analysis Model at the BPPT-PM of Majalengka Regency.

\section{Literature Review}

\subsection{Review of E-Government}

Information technologies play an important role in government (Vena V 2011), enhanced quality of service has been a major component of public administration reform over the past two decades, and the use of ICT in order to generate improvements in services has been a primary driver for e-government activity (Latif al Hakim 2007). There have been many studies conducting investigation on E-Government. Most researchers refer to the same meaning, that E-Government is the use of information and communication technology as the basis for carrying out the function of the government as a public service provider, that in the end it can realize better public service performance (Pathak and Kaur 2014); (Mungai 2017); (Visser and Twinomurinzi 2008). However, in its implementation of e-Government, numerous obstacles are still found especially regarding human resources which lead to limited capabilities of IT (Pederson 2016). E-Government is a transformation which has the best solution in solving bureaucratic problems through the use of technology and information in realizing a more accountable performance of an organization (Kareem and Haseeni 2015); (Desta and Yoon 2017).

\subsection{Review of SWOT Analysis}

SWOT analysis is a tools in development of new strategic plan in the organizations (Erwin, Paul, and Peter 2019). SWOT analysis has often been adopted in order to assess a given decision, project or policy directive in a systematic manner, and in order to get a realistic picture of a destination (Andermo 2014). In the Research SWOT analysis model a tools strategic to answer the problems in E-Government in order to minimize the limitations of E-Government in its implementation. Many of research has conducted on SWOT analysis in relation to the implementation of E-Government as well (Rudi and Prasetia Muis 2018); (Elsheikh and Azzeh 2017); (Rezazadeh, Hamidi, and Rezazadeh 2011). Research of (Winarni 2018) SWOT analysis is a tools in development of Bureaucracy based on technology (E-Government). In this research, SWOT analysis is carried out before mapping 
the conditions of external factors and internal factors in the forms such factors as strengths, weaknesses, opportunities and challenges as follows:

\section{Strength factor}

1. Government policy support

2. Cooperation between public and private sectors.

3. Progress of E-Government processes in several government entities.

\section{Weakness factor}

1. Limited human resources

2. Limited facilities and infrastructure

3. Limited budget

\section{Opportunity factor}

1. Private investment

2. The presence of international airport

3. IT development

\section{Threat Factor}

1. Globalization, free trade and openness of world's economies

2. Social, political and international economic conditions

3. Fluctuating economic stability

\section{Research Method}

The research method applied is a descriptive qualitative. This model has been widely used in the formulation of strategic plans for national and international companies as well as several government institutions in Indonesia. This research implementation is divided into three stages, namely:

1) Identifying the BPPT-PM governance environment in Majalengka Regency through observation, literature study and interview with the Head of Institution, Secretariat, Investment Licensing Department, Non-Investment Licensing Department, Investment Department, and the staffs who are directly involved in managing the licensing sector.

2) Based on the research, an analysis of the external environment in general about the condition of Papua was done using PEST analysis (Politics, Economy, Social, and Technology) that can influence the development and utilization of E-Government. The analysis of internal and external business environments is done using SWOT as the basis for formulating E-Government development strategies at the BPPT-PM of Majalengka Regency.

3) Arranging the formulation of future E-Government development.

4) All of the information is used to identify the factors of strengths, weaknesses, opportunities and threats collected from questionnaire questions and interviews with 30 BPPT-PM officials who are directly involved in the activities of providing licensing services to the public. The results of the questionnaire are used to identify the priority factors and as key internal and external factors which continue to formulate relevant strategies. 


\section{Results and Discussion}

The assessment results of the internal factors by considering aspects of strengths and weaknesses as well as the external factors by considering aspects of opportunities and threats are obtained as follows.

1. The strength score $(\mathrm{S})$ is 5.00 while the weakness score $(\mathrm{W})$ is 1.709 , thus if $\mathrm{S}-\mathrm{W}$ the $\mathrm{X}$ axis is 3.291

2. The opportunity score $(\mathrm{O})$ is 4.988 while the threat score $(\mathrm{T})$ is 1.504 , thus if $\mathrm{O}-\mathrm{T}$ the $\mathrm{Y}$ axis is 3.484

Then the coordinates of X-axis (SW) and the Y-axis (OT) are set out in the SWOT analysis diagram so as it can be identified that the realization of service quality development strategies is in quadrant I, meaning that it supports the aggressive strategy, namely the strategy that maximizes or prioritizes element of strengths to seize the existing opportunities (ST).

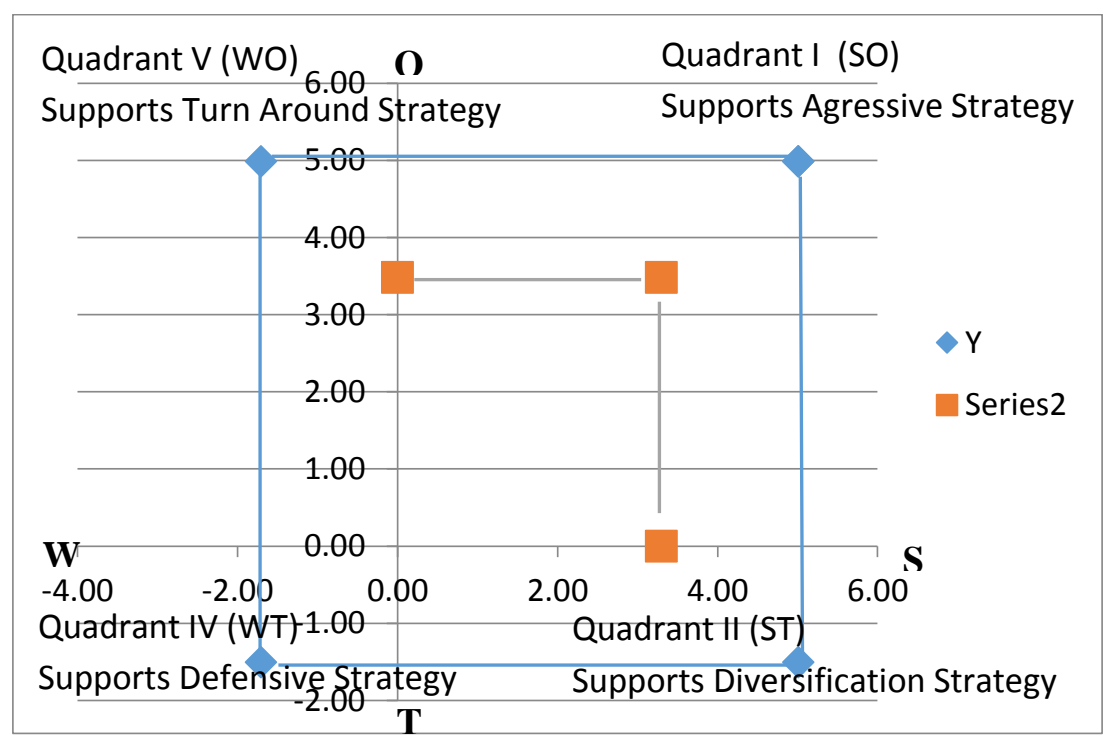

Figure 1. Planning Strategy Quadrant

Source : Processing Data Result

From the results of SWOT analysis, the position of the realization of service quality development program is found. Then the alternative strategis can be designed into consideration in formulating the development of E-Government at the BPPT-PM of Majalengka. (David 2011) states that regardless of the number of opportunities and key threats included in the matrix, the weighted score of an organization is 4.0 and the lowest value is 0.1 . E-Government development strategy to realize quality services is set based on the main issues and SWOT analysis (strengths, weaknesses, opportunities, and threats), and policy directions. Based on the results of SWOT analysis conducted, it can be seen that EGovernment development strategy in BPPT-PM of Majalengka is in quadrant I, which eventually results in a new strategic alternative assessed to support the process of realization of service quality, namely aggressive (offensive) strategy. This is a strategy of development of very good situations because there are strengths to be utilized to seize profitable 
opportunities. The results of SWOT analysis and alternative strategies that are considered in preparing the development plan are presented in the following SWOT Matrix Table:

Table 1. Issues and Elements of SWOT Analysis Results

\begin{tabular}{|c|c|c|}
\hline External factors & Strengths (S) & Weaknesses (W) \\
\hline Opportunities (O) & $\begin{array}{l}\text { SO strategies } \\
\text { a) Optimization of ICT-based } \\
\text { one door service program } \\
\text { b) Providing a master-planning } \\
\text { guideline for E-Government } \\
\text { as a standardization of ICT- } \\
\text { based services }\end{array}$ & $\begin{array}{l}\text { WO Strategies } \\
\text { a) Development of ICT skill of } \\
\text { human resources through } \\
\text { formal and informal } \\
\text { channels } \\
\text { b) gradual development of } \\
\text { facilities and infrastructures } \\
\text { to support E-Government }\end{array}$ \\
\hline Threats (T) & $\begin{array}{l}\text { ST strategies } \\
\text { a) Utilization of the availability } \\
\text { of computers, software and } \\
\text { networks for fast, precise } \\
\text { and integrated services, } \\
\text { along with the availability of } \\
\text { accurate and informative } \\
\text { information. } \\
\text { b) Developing a General Plan } \\
\text { for E-Government } \\
\text { development }\end{array}$ & $\begin{array}{l}\text { WT Strategies } \\
\text { a) Gradual development of } \\
\text { knowledge from the levels } \\
\text { of staffs to leaders in order } \\
\text { to accelerate the } \\
\text { development of E- } \\
\text { Government applications. } \\
\text { b) Designing a standard for } \\
\text { ICT-based services. }\end{array}$ \\
\hline
\end{tabular}

Source : Processing Data Result

The SO strategy is a way to reach goal using strengths to achieve the maximum possible opportunities. Then WO strategy is determined by minimizing or reducing existing weaknesses to seize opportunities while the ST strategy is determined by utilizing existing strengths to deal with or reduce threats. Last, WT strategy is determined by minimizing or reducing weaknesses to deal with or reduce the threats found. The linkage analysis of alternative strategies can be shown in the following table.

Table 2. E-Government Development Strategies at BPPT-PM

\begin{tabular}{|c|c|c|c|c|c|c|c|c|}
\hline \multirow{2}{*}{\multicolumn{2}{|c|}{ STRATEGY }} & \multicolumn{5}{|c|}{ LINKAGE } & \multirow{2}{*}{ SCORE } & \multirow{2}{*}{ RANK } \\
\hline & & $\mathrm{A}$ & B & $\mathrm{C}$ & $\mathrm{D}$ & $\mathrm{E}$ & & \\
\hline \multicolumn{9}{|c|}{ S-T STRATEGIES } \\
\hline ST-1 & $\begin{array}{l}\text { Utilization of the availability of } \\
\text { computers, software and networks } \\
\text { for fast, precise and integrated } \\
\text { services, as well as the } \\
\text { availability of accurate and }\end{array}$ & 2 & 2 & 3 & 2 & 3 & 12 & VII \\
\hline
\end{tabular}




\begin{tabular}{|c|c|c|c|c|c|c|c|c|}
\hline & informative information. & & & & & & & \\
\hline ST-2 & $\begin{array}{l}\text { Developing a General Plan for E- } \\
\text { Government development }\end{array}$ & 3 & 3 & 2 & 2 & 2 & 12 & VIII \\
\hline \multicolumn{9}{|c|}{ S-O STRATEGIES } \\
\hline SO-1 & $\begin{array}{l}\text { Optimization of ICT-based one } \\
\text { door service program }\end{array}$ & 3 & 3 & 2 & 2 & 3 & 13 & II \\
\hline SO-2 & $\begin{array}{l}\text { Providing a master-planning } \\
\text { guideline for e-government as a } \\
\text { standardization of ICT-based } \\
\text { services }\end{array}$ & 3 & 4 & 4 & 2 & 4 & 17 & $\mathrm{I}$ \\
\hline \multicolumn{9}{|c|}{ W-O STRATEGIES } \\
\hline $\begin{array}{l}\text { WO- } \\
1\end{array}$ & $\begin{array}{l}\text { Development of ICT skill for } \\
\text { human resources through formal } \\
\text { and informal channels }\end{array}$ & 2 & 2 & 3 & 2 & 3 & 12 & III \\
\hline $\begin{array}{l}\text { WO- } \\
2\end{array}$ & $\begin{array}{l}\text { Gradual development of facilities } \\
\text { and infrastructures to support E- } \\
\text { Government }\end{array}$ & 3 & 3 & 3 & 2 & 3 & 12 & IV \\
\hline \multicolumn{9}{|c|}{ W-T STRATEGIES } \\
\hline WT-1 & $\begin{array}{l}\text { Gradual development of } \\
\text { knowledge from the levels of } \\
\text { staffs to leaders to accelerate the } \\
\text { development of E-Government } \\
\text { applications. }\end{array}$ & 2 & 3 & 2 & 3 & 3 & 12 & V \\
\hline WT-2 & $\begin{array}{l}\text { Designing a standard for ICT- } \\
\text { based services }\end{array}$ & 2 & 3 & 2 & 2 & 3 & 12 & VI \\
\hline $\begin{array}{l}\text { Info } \\
a= \\
b= \\
c= \\
d= \\
e=\end{array}$ & $\begin{array}{l}\text { rmation: } \\
\text { Human Resources } \\
\text { Method } \\
\text { Facilities and infrastructure } \\
\text { Funds } \\
\text { Organization }\end{array}$ & & $\begin{array}{l}\text { Val } \\
1= \\
2= \\
3= \\
4= \\
5=\end{array}$ & & ate & & & \\
\hline
\end{tabular}

Source : Processing Data Result

In this research, even though the position of integrated service development at the BPPTPM is in the first quadrant, and it is usually only a strategic direction for the quadrant was compiled. In this case, however, the strategic direction for other quadrant positions (Quadrant II, III, and IV) are arranged. It is to accommodate a combination of other SWOT factors outside the direction of SO strategies, and as alternatives to the additional strategies which priorities are below the priority of SO strategy. Based on the SWOT analysis that has been carried out to analyze the development of optimal and sustainable integrated services at the BPPTPM of Majalengka by considering the weight of each internal and external factor, there are 2 SO strategies, 2 ST strategies, 2 strategies WO, and 2 WT strategies obtained as shown in the SWOT analysis matrix. In order to be structured, each strategy needs to be ranked according to the obtained scores by analyzing the interrelations of each of these strategies with the actual and important elements owned by the BPPTPM of Majalengka 
Regency. This is to achieve the goal of developing optimal and sustainable services. Important elements related to the implementation of the strategies are the existence of human resources to realize the strategies, the existence of methods as a guide that supports the strategy implementation, the existence of facilities and infrastructures, the existence of potential funds or budgets to support the intended strategies, and the existence of organizations or institutions that can be mobilized to succeed the strategies. The actual elements will provide values and scores for each alternative strategy that will determine the priorities of each alternative strategy. Based on the aforementioned analysis results of SWOT and policies, the integrated service strategies are described in the following scheme.

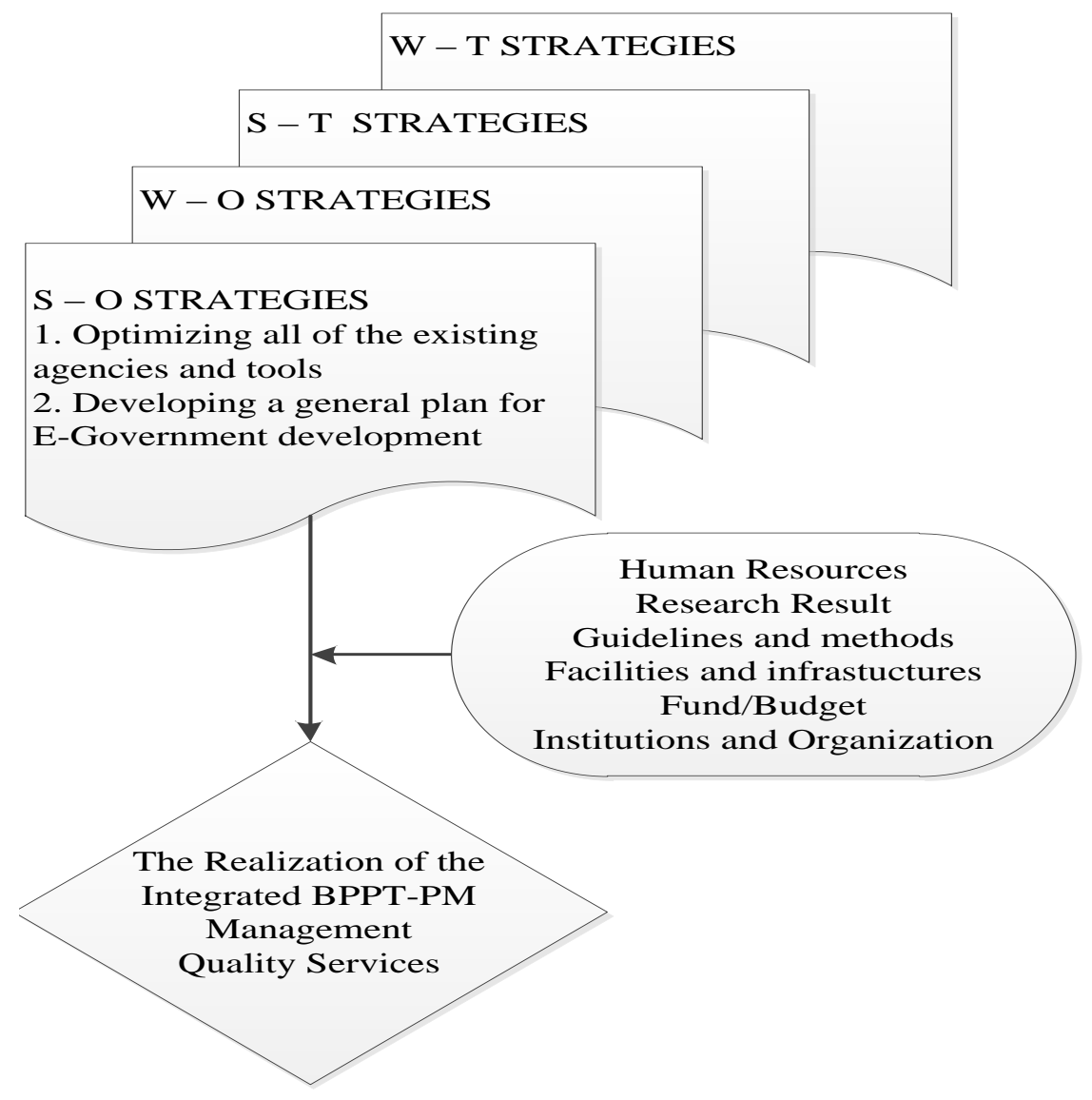

Figure 2. E-Government Strategies at the BPPTPM of Majalengka Regency Source : Processing Data Result

\section{Conclusions}

Based on this present research which involves the SWOT analysis for E-Government master planning at the BPPT-PM of Majalengka Regency, some conclusions are drawn as follows :

1. This research results in an analysis of the master plan for e-government strategies at the BPPT-PM of Majalengka Regency using SWOT analysis model. 
2. Strategies that can be used in achieving the goal of E-Government are: optimization of onestop service program through ICT, development of a master-planning guideline for EGovernment as the standardization of ICT-based services, development of ICT skill for human resources through formal and informal channels, gradual development of facilities and infrastructures to support E-Government, utilizing the availability of computers, software and networks for fast, precise and integrated services, as well as the availability of accurate and informative information, developing a General Plan for E-Government Development, gradual development of knowledge from the levels of staffs to leaders to accelerate the development of e-Government applications and designing a standard of ICTbased service regulations.

3. Strategy that can be used to reach the goal of E-Government implementation to achieve quality services is the aggressive (offensive) strategy, which refers the strategy of development regarding very good situations because there strengths to be utilized to seize profitable opportunities.

\section{References}

Abdulla, Hedi Mustafa, and Karwan Hushyar Sherwani. 2017. "A Swot Analysis of Readiness for E-Government: As a Case of Kurdistan Regional Government." International Journal of Social Sciences \& Educational Studies 3(4): 66-72.

Andermo, Ani. 2014. "Revealing Georgia 's Tourism Potential." Södertörn University School.

David, R. Fred. 2011. Strategic Management. New Jersey: Pearson Prentice Hall.

Desta, Kenenissa, and C. Cho Yoon. 2017. "Evaluating E-Government Implementation in Public Service Delivery." Journal of Marketing Thought 4(1): 1-10.

Elsheikh, Yousef, and Mohammad Azzeh. 2017. "Prioritize E-Government Strategies Using SWOT-Ranked Voting Analysis Technique: The Case of Jordan." IJCSNS International Journal of Computer Science and Network Security 17(1): 1-7.

Erwin, Loh, W. Long Paul, and Spurg Peter. 2019. Textbook of Medical Administration and Leadership. ed. Loh Erwin. Singapore: Springer Nature Singapore Pte.Ltd.

Ha, Huong. 2012. "A New SWOT Analysis of an E-Government System." Integrated Information and Computing Systems for Natural, Spatial, and Social Sciences: 74-95.

Hussain, Abid, Ch Saghir, and Atif Khalil. 2016. "Strengths, Weaknesses , Opportunities and Threats : An Analysis of University of the Punjab." Bulletin of Education and Research 38(2): 229-47.

Kahraman, Cengiz, Nihan Çetin Demirel, and Tufan Demirel. 2007. "Prioritization of EGovernment Strategies Using a SWOT-AHP Analysis: The Case of Turkey." European Journal of Information Systems 16(3): 284-98.

Kareem, Mohanad Ali, and Zeena Jabber Haseeni. 2015. "E-Government and Its Impact on Organizational Performance." International Journal of Management and Commerce Innovations 3(1): 664-72. 
Latif al Hakim. 2007. Global E-Government: Theory Aplications and Benchmarking. United States of America: Idea Group Publishing.

Mungai, Alfred Ngugi. 2017. "E-Government Strategy Implementation and Performance of the Public Sector in Kenya." International Academic Journal of Human Resource and Business Administration 2(3): 301-38.

Pathak, Monika, and Gagandeep Kaur. 2014. "Impact of E-Governance on Public Sector Services." International Journal of Emerging Research in Management \&Technology 3(4): 100-103.

Pederson, Keld. 2016. "E-Government in Local Government: Challenges and Capabilities." Electronic Journal of E-Government 14(1): 99-116.

Rezazadeh, F, N Hamidi, and Z Rezazadeh. 2011. "A SWOT and PEST Analysis of EGovernment in Iran." 5Thsastech.Khi.Ac.Ir: 1-9.

Rudi, and Abdul Prasetia Muis. 2018. "SWOT Analysis and Town Matrix E-Government on Tana Tidung City of Kalimantan Utara." ELINVO(Electronics, Informatics, and Vocational Education) 3(May): 46-51.

Al Salmi, Muatasim Anwar Ahmed, and Norlena Bt Hasnan. 2015. "SWOT and TOWS Matrix E-Government Analysis Review on Sultanate of Oman." International Journal of Learning \& Development Vol. 5(No. 4): 13-23. http://dx.doi.org/ 10.5296 / i jld . v 5 i 4.8641 .

Tresna, Pratami Wulan. 2017. "External and Internal Environment Analysis ( A Study in Tasikmalaya City Embroidery Industry )." Review of Integrative Business and Economics Research 6(1): 401-11.

Vena V, Raman. 2011. "E-Government in Malaysia: Barriers and Progress.” In Handbook of Research on Information Communication Technology Policy: Trends, Issues and Advancements, Hershey, Pennsylvania, USA: IGI Global, 1-792.

Visser, Wikus, and Hossana Twinomurinzi. 2008. "E-Government \& Public Service Delivery: Enabling ICT to Put 'People First ' - A Case Study from South Africa." Systemics, Cybernetics and Informatics 6(6): 36-41.

Winarni, Liliek. 2018. "Development of Bureaucracy Based on Technology ( E-Government ) in the SWOT Perspective." International Journal of Progressive Sciences and Technologies: 59-63. 